\title{
The Effect Of Aggregate Expenditure On Gross Regional Domestic Product And Its Impact On Human Development Index, Labor Absorption And Poverty In Tangerang Regency
}

\author{
Karnawi Kamar \\ Lecturer of STIE Insan Pembangunan
}

\begin{abstract}
This research examines the effect of aggregate expenditure that consists of household consumption, government consumption, investment and net exports on Gross Regional Domestic Product and its impact on Human Development Index, labor Absorption and Poverty in Tangerang Regency. The research method used is explanatory research with techniques of Simple Linear Regression analysis and multiple linear regression analysis. The results showed that: household consumption, government consumption, investment and net exports both simultaneously and partially give effect positively on Gross Regional Domestic Product. Further Gross Regional Domestic Product gives positive effect on Human Development Index. Human Development Index gives positive effect on labor absorption. Human Development Index and labor absorption either simultaneously or partially give negative effect on poverty in Tangerang Regency.
\end{abstract}

Keywords: Gross Regional Domestic Product, Human Development Index, Labor Absorption and Poverty

\section{Introduction}

Tangerang regency is one of area in Banten Province which has been expanded into 3 (three) district of Level II, namely: Tangerang regency, Tangerang city and South Tangerang City (BPS Kabupaten Tangerang, 2013, p. 1). The large increase of effective demand that exists in the economy, the large increase in level of production that will be achieved by corporate sector. This situation will naturally lead to increase in the level of economic activity, the increase of labor employing and the increase of production factors using. (Sadono Sukirno, 2010, p. 85). In a macroeconomic analysis that exists now the aggregate expenditure in the economy also includes government expenditure and exports. Meanwhile, according to Sadono Sukirno (2010, p. 258), the aggregate demand is distinguished to five (5) components: household consumption, investment of private and government, government consumption expenditure, export and import. Spending of public consumption is one of the macroeconomic variables. Spending of one's consumption is part of his income spent. If spendings of everyone consumption within a country are summed, the result is spending of public consumption of the country involved. One's consumption is directly proportional to his income. In an open economy, the understanding of aggregate demand is no longer limited to demand that is from domestic. Two important expenditure activities of other in an open economy that is export and import. If the export and import activities are taken into account in determining the balance of national income, the analysis of economic activity in a country has fully described in actuality in the form of reality. So in actual economic activity, the economy can be divided to four (4) sectors, coupled with the foreign sector where export and import activities are run. (Sadono Sukirno, 2010, p. 201).

The last few years HDI in Tangerang always increases. The increasing of HDI indicators generally because the development programs that have been implemented by local government and get support from the whole society towards development programs that have been implemented by local government. However, by seeing the development of HDI number each year, achievement of human development index progress in Tangerang did not seem too significant.

\section{Theoretical Study}

Economic growth is measured by the increase in national income per capita at national economy level and the increase in regional income (region) per capita at region economy level, many factors affect the increase of income per capita, such as: population growth, investment, change in marginal comparison between output and capital, climate change and etc. In addition, economic growth is determined by factor multiplier (multiplier) investment and accelerator (accelerator), as proposed by Samuelson in Sumitro Djojohadikusomo (1991, p. 87) stating that: As for economic development, according to Sadono Sukirno (2006, p. 3), is defined as a series of businesses in an economy to develop the economic activities so that infrastructure more widely available, company is more and more and more growing, the level of education is higher and technology is more increasing. As implication of the development the employment opportunity is expected to be grow, income level is rising and prosperity of society becomes higher. 
Todaro (2000, p. 21) defines broadly development as a process of continuous improvement on a society or a social system as a whole towards a better life or more humane.

Economic development is also defined as a change that increases in national production capacity. The increase is certainly reflected in economic growth, and economic growth indicator reflected in the increase of income per capita in real terms. As said by Triyanto Widodo Suseno (1991, p. 35) that the income per capita or income per person can be determined by comparing between Gross Domestic Product (GDP) with a population at a given time.

The success of economic development of a country is influenced by several factors. Based on the development experience of developed countries, the success of development is basically influenced by two main elements, namely the economic element and non-economic element.

a. Economic factors include:

1) Human Resources

2) Natural Resources

3) Capital Formation

4) Technology and Entrepreneurship

b. Non-economy Factors include:

1) Social institutions

2) Political situation and institutional

3) Social culture

Investment in human resources, for example in the form of educational development, vocational schools, training and skills courses will bring growth in improving the quality of human resources, so it will produce a skilled labor which will further smooth the productive activities. Besides the activities of specific programs such as surveillance of the disease, improved health and improving nutrition should be prioritized so that they can work more productively.

\section{A. Gross Domestic Product}

Gross Domestic Product by Sadono Sukirno (2010, p. 34), can be interpreted as the value of goods and services that are produced in a country within a particular one. In an economy, in the developed countries and developing countries, goods and services are produced not only by companies belonging to the country's population but also by residents of other countries. The national production created by product factors that are from abroad always found. Multinational companies operate in different countries and help raise the value of goods and services produced by those countries.

Gross Domestic Product as formulated by Sadono Sukirno, (2010, p. 35) as follows: GDP = GNP - PFN of LN. There are three (3) ways or approach of calculating GDP, namely approach from aspects of spending, income and production. The three methods of calculating produce the same value/figures. The basis of calculation that the ultimate value of the goods can be returned to the contribution of each input that is used, so that when the value of an item, namely the price bought by someone (said expenditure), so that the expenditure, will be equal to the value of goods, and will be the same similarly with the income amount received by each of production factors used in making the goods.

According to Mudrajad Kuncoro (2013, p. 31), in the expenditure approach, GDP is all the components of final demand consisting of household consumption expenditure and non-profit private institution, government consumption expenditure, fixed capital formation of gross domestic or often called investment, changes in inventories and net export that is export minus import. GDP is the whole of government and public consumption, government expenditure, investment and export minus import in certain region. GDP formula as follows:

$$
\mathrm{GDP}=\mathrm{C}+\mathrm{G}+\mathrm{I}+\mathrm{NX}
$$

Where :

$\mathrm{C}=$ the whole public consumption and consumer spending.

$\mathrm{G}=$ the amount of government expenditure

$\mathrm{I}=$ the amount of capital expenditures

$\mathrm{NX}=$ net export is export minus import $(\mathrm{NX}=$ Export - Import $)$

\section{B. Gross Regional Domestic Product}

Domestic product, according to Mudrajad Kuncoro (2013, p. 229) is all goods and services as a result of the economic activities that operate in the domestic territory, regardless of whether the factors of production 
derived from or owned by residents of the area. The fact is that most of the factors of production used in production activity in a region from other regions or from abroad, and vice versa the factor of production owned by resident of the area participate in the process of production in other regions or abroad. This causes the value of domestic product which arises in an area is not the same as earned income by residents of the area. With the flow of income flowing between these regions (including those from the country and abroad) that are generally in the form of wages/salaries, interest, dividend and profit then appearing the difference between the domestic product and regional product.

GRDP at prices base prevails to illustrate the added value of goods and services which is calculated uses prices prevailing at each year, while the GRDP at constant prices shows the added value of goods and services calculated uses prices prevailing in a year

\section{Human Development Index}

Human Development Index according to Becker and Posner (2007, p. 8) : "The HDI is very often presented as an objective measure by which to judge and compare all nations. So, even assuming the previous commenters are correct about the HDI's intended purpose, it has (predictably) been used in ways it was not intended."

Human Development Index (HDI) is the most ambitious effort and the latest in analyzing the comparative status of socio-economic development, both in NSB and the developed country have been done by the UNDP (United Nations Development Program) in a systematic and comprehensive. (Mudrajad Kuncoro, 2000, p. 27).

The concept of HDI is successfully applied to rank all countries as a whole can be categorized into three (3) large groups. The first group are the countries that the low level of human development $(0,0$ to 0,50$)$, medium $(0,50$ to 0,79$)$ as well as countries with high human development levels (scores of 0,80 to 1,0$)$, However, each year HDI only measures the levels of human development relative, not absolute, and the focus is on the end result of development (survival, knowledge and freedom of material choice or quality of living standards) rather than means (purely income or GNP per capita), (Todaro, 2000, p. 88).

Index of the three components of HDI can be calculated by comparing the difference between the value of indicator and determiner of minimum value to the difference between the indicator determiner of maximum and minimum, or briefly it can be written as follows: Index $\mathrm{X}_{(\mathrm{i})}=\left[\mathrm{X}_{(\mathrm{i})}-\mathrm{X}_{(\mathrm{i}) \min }\right] /\left[\mathrm{X}_{(\mathrm{i}) \max }-\mathrm{X}_{(\mathrm{i}) \min }\right]$ In which :

$\mathrm{X}_{(\mathrm{i})} \quad=$ Indicator to- $\mathrm{i}(\mathrm{i}=1,2,3)$

$\mathrm{X}_{(\mathrm{i}) \max }=$ Maximum value of $\mathrm{X}(\mathrm{i})$

$\mathrm{X}_{(\mathrm{i}) \min }=$ Minimum value of $\mathrm{X}(\mathrm{i})$

Based on the procedure above, HDI can be calculated by the equation: $\mathrm{HDI}=1 / 3\left[\mathrm{X}_{(1)}+\mathrm{X}_{(2)}+\mathrm{X}_{(3)}\right]$

In which :

$\mathrm{X}_{(1)}=$ Index of life expectancy at birth

$X_{(2)}=$ Index of education $=2 / 3$ (Index of literacy) $+1 / 3$ (Index of mean years of schooling

$\mathrm{X}_{(3)}=$ Index of living standards

The range between the minimum and maximum values for indicators included as a component of HDI are (UNSFIRS in Mudrajad Kuncoro, 2013, p. 223):

1. Life expectancy at birth

$$
=25-85 \text { (Standar UNDP) }
$$

2. The rate of literacy

$$
=0-100(\text { Standar UNDP) }
$$

3. Mean years of schooling $=0-15$ (Standar UNDP)

4. Consumption adjusted per capita $\quad=300.000-732.720$

Based on the description of theory above it can be stated that Human Development Index is an indicator used to measure or analyze the status of a country's socio-economic development.

\section{Labor Absorption}

Based on the Law of Republic of Indonesia Number 13 of 2003 on Labor Chapter I Article 1 Verse (2) states that labor is any person who is able to work in order to produce goods and/or services, both meeting a need for self and for the community.

According to Mudrajad Kuncoro (2013, p. 66), rate of Labor Force Absorption/APAK (employment rate) is a rate indicating how many the total of labor force that state are working at the time of enumeration, which can be calculated by the formula:

Total of Labor force working

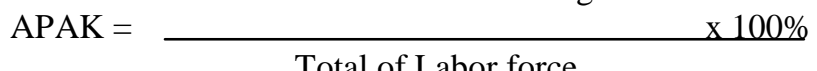

Total of Labor force 
According to Sadono Sukirno (2010, p. 13) Unemployment is a condition in which a person belonging to the labor force wants to get a job but can not get it. While According to Abdul Hakim (2002, p. 240), unemployment is the population in working age who do not have any work who are actively looking for work.

Yuyun Wirasasmita (2008, p. 3), states that open unemployment is population who are unemployed because they have not gotten a job. Underemployment is the population who work under 35 hours per week. Underemployed visible is population people who work less than 14 hours per week. While underemployed invisible (unemployment imperceptibly) has low productivity and low income.

\section{E. Poverty}

Poverty can be linked to the limitations of rights of social, economic and political, thus causing susceptibility, adversity, and helplessness. A similar analysis was stated by Gustavo Gutierres in Chen (2002, p. 51) about the problem of poverty in Latin America, that the direction of sociological, poverty is a social injustice related to the structure of the economic, political and social culture.

Smith $(2005$, p. 12) explains that in fact not all poverty in every time and place is a trap. Poverty may be temporary and in some cases people can be tried and succeeded to get out of poverty. However, poverty becomes a trap when a vicious circle of poverty thwart the efforts of poor.

Chamber in Suradi (2007, p. 6) defines poverty as a state of poverty and disadvantage, a state of minus (deprivation). Then by Sen in Suradi (2007, p. 6) reveals that there is a core of absolute from poverty. Famine stricken them becomes a perspective of poverty, as well as in social incompetence and inability to educate children (education) and health care for children.

Another case with Sachs (2005, p. 244) states that the poor are very poor at least they don't have six of major capitals, namely:

1. Human capital:

2. Business capital:

3. Infrastructure capital:

4. Natural capita:

5. Public institutional capital:

6. Knowledge capital:

Human poverty index (Human Poverty Index) has been allowed by UNDP (United Nations Development Program). General argument used by UNDP which is a benchmark of poverty is if someone is not able to achieve (or even not having access) to the basic public facilities and the level of their own quality of life is low. So it's not just how much per dollar per capita that they were able to achieve every day.

\section{F. Consumption of Household}

Case and Fair (2004, p. 71), state that in each period (week, month, year, etc.) household receives a number of aggregate income (Y). In a closed economy, household can only do two (2) terms of the income which are household can purchase goods and services that can consume or save.

Consumption function (consumption function) is $\mathrm{C}=\mathrm{cY}$. There are different versions of consumption function proposed by economists (often by entering other variables besides $\mathrm{Y}$ such as wealth, income distribution index, and so on). The forms of consumption function above is the simplest. Another simple form is $\mathrm{C}=\mathrm{a}+\mathrm{cY}$, which a shows the level of minimal consumption spending.

According to Pratama Rahardja and Mandala Manurung (2008, p. 225), household consumption spending has the largest portion in the total of aggregate expenditure. Remembering that a large portion of it, then household consumption also has a great influence on the stability of the economy. Household consumption is endogenous. In a sense, the amount of household consumption is closely related to the factors considered to influence it.

\section{G. Government Consumption}

Government expenditure is one element of aggregate demand. The concept of national income calculation by spending approach states that $\mathrm{Y}=\mathrm{C}+\mathrm{I}+\mathrm{G}+\mathrm{X}-\mathrm{M}$. This formula is known as national income identity. Variable Y symbolizes national income (in the broad sense), and reflects the aggregate supply. While variable in the right side is called the aggregate demand. Variable G symbolizes government expenditure (government expenditure). By comparing the value of $\mathrm{G}$ to $\mathrm{Y}$ and observing them from time to time it can be known how great the contribution of government expenditure on the formation of aggregate demand or national income. With that, it can be analyzed how important the role of government in the national economy. (Dumairy, 2004, p. 157). 
Government consumption is the purchase of goods and services that will be consumed, such as paying the school teacher salaries, purchasing the stationeries and paper to use and buying gasoline for government vehicles. (Sadono Sukirno, 2010, p. 38).

\section{H. Investment}

Investment according to economic science in Case and Fair (2004, p. 77), is something that is used to create future value. Investment always refer to the creation of capital stock. Investment is also defined as the purchase of building and new equipment and additional supplies by company, which is all of them added to the capital stock of company. Investment is a variable of flow that describes the additions to capital stock in a given period. The company's decision about how much should be invested each period is defined by many factors.

According to Yuyun Wirasasmita (2008, p. 5), the impact of the overall investment can be approached with the concept of elasticity, namely:

$$
\text { Elasticity I (Investment })=\frac{\Delta \text { GDP } / \text { GDP }}{\Delta \mathrm{I} / \mathrm{I}}
$$

Referring to the opinion of Harrod Dommar in Suryana (2000, p. 72), that capital accumulation has a double role, that raises the income and the increase in production capacity. Capital formation will increase income and will expand employment opportunities and raise further investment.

Yuyun Wirasasmita (2008, p. 2), capital accumulation or capital formation refers to the addition of the quantity of capital to produce more output. While the productivity factors of capital refers to the quality, namely more efficient use of capital.

\section{Net Export}

Export by Sitiarava Rizema Putra (2011, p. 9), is the transportation process of goods or commodities from one country to another. This process is often used by companies with scale of small to medium businesses as a key strategy to compete on an international level.

Sadono Sukirno (2010, p. 209), states that net export is export value that is done by a country in a given year that is reduced by the value of import in the same period. A country's export, all or part of its value, is the goods and services produced in the country. Therefore, the value shall be calculated in national income. Imported good is product from other countries, therefore it is unnecessary calculated in national income.

Based on the theory description above it can be stated that net export is the value of export of goods from one country in one year that is reduced by the value of import of goods from other countries to the country in one year.

\section{Research Methodology}

Place or object of research is carried out in Tangerang regency, Banten province. Data needed in this research is secondary data collecting that is time series (time series) with a stretches of time for 23 years, namely: from 1990 to 2012. The research was undertaken with secondary data obtained from various institutions, namely: Central Bureau of Statistics of Tangerang regency, Development Planning Agency at SubNational Level of Tangerang regency and Regional Office of Manpower and Transmigration Department.

The analysis technique used to test hypotheses about the factors that affect the Gross Regional Domestic Product and its implications on Human Development Index, Labor Absorption and Poverty is Linear Regression Analysis of Simple and multiple with Ordinary Least Square (OLS) technique. Assumption on which the prerequisite in the use of OLS in linear regression is a classic assumptions about residual or error term (disturbance term) that must be met. To illustrate the multiple analysis, then regression model will be estimated as follow:

$$
Y_{t}=\beta_{0}+\beta_{1} X_{1 t}+\beta_{2} X_{2 t}+\beta_{3} X_{3 t}+\ldots \ldots .+\beta_{k} X_{k t}+\varepsilon_{t}
$$

\section{Analysis Results And Discussion}

\section{Testing of Model 1}

The effect of household consumption, government consumption, investment and net export simultaneously on Gross Regional Domestic Product (GRDP), it can be seen in the table below. 
Table 4.1. Testing of the Effect of Household Consumption, Government Consumption, Investment and Net Export on Gross Regional Domestic Product (GRDP)

Dependent Variable: Y

Method: Least Squares

Date: 12/17/13 Time: 09:00

Sample: 19902012

Included observations: 23

\begin{tabular}{crrrc}
\hline \hline \multicolumn{1}{c}{ Variable } & Coefficient & Std. Error & t-Statistic & Prob. \\
\hline \hline C & 0.206000 & 3.318000 & 0.062000 & 0.951000 \\
X1 & 0.407000 & 0.131000 & 3.111000 & 0.006000 \\
X2 & 0.371000 & 0.137000 & 2.702000 & 0.015000 \\
X3 & 0.257000 & 0.104000 & 2.467000 & 0.025000 \\
\multicolumn{1}{|c|}{0.358000} & 0.104000 & 3.429000 & 0.003000 \\
\hline \hline R-squared & 0.845000 & Mean dependent var & & 28.048500 \\
Adjusted R-squared & 0.809000 & S.D. dependent var & & 10.266600 \\
S.E. of regression & 1870.564000 & & & \\
Sum squared resid & 342.901000 & & & \\
F-statistic & 23.184000 & & & \\
Prob(F-statistic) & 0.000000 & & & \\
\hline \hline
\end{tabular}

Source: Data Processing of Eviews 7.0 (2013

Based on the output result in the table above shows that the contribution of the effect of household consumption, government consumption, investment and net export together on Gross Regional Domestic Product in Tangerang regency is $84,5 \%$ ( $\mathrm{R}$ Square $=0845000$ ), while the remaining $15,5 \%$ is influenced by other factors that not studied as non-profit institution expenditure, change in the stock and etc. The value of adjusted $\mathrm{R}^{2}$ (Adjusted R-squared) is obtained by 0,809000 .

Hypothesis test result of $\mathrm{F}$ can be explained as follows:

a. Result of $\mathrm{F}$ table with denominator degree $=\mathrm{n}-\mathrm{k}-1=23-4-1=18$ and numerator degree $=\mathrm{k}-1=5-$ $1=4$ is obtained F Table on the degree of confidence of $95 \%$ amounting to 2,96 .

b. Result of F count obtained F count is 23,184000.

c. $\quad F_{\text {count }}$ larger than $\mathrm{F}_{\text {table }}(23,184000>2,96)$, the effect of household consumption, government consumption, investment and net export simultaneously on Gross Regional Domestic Product in Tangerang Regency is significant.

a) The Effect of Household Consumption, Government Consumption, Investment and Net Export partially on Gross Regional Domestic Product (GRDP)

Contribution effect of household consumption, government consumption, investment and net export partially on Gross Regional Domestic Product may be shown in the table below.

Table 4.2. Test Result of Partial Effect of Household Consumption, Government Consumption, Investment and Net Export on Gross Regional Domestic Product

\begin{tabular}{|c|l|c|c|c|c|}
\hline No. & \multicolumn{1}{|c|}{ Partial Effect } & $\mathbf{b}_{\mathbf{i}}$ & $\mathbf{T}_{\text {count }}$ & P-Value & $\begin{array}{c}\text { Standar } \\
\text { Error }\end{array}$ \\
\hline 1. & $\begin{array}{l}\text { Contribution of } \\
\text { Household Consumption } \\
\left(\mathrm{X}_{1}\right)\end{array}$ & 0,407000 & $3,111000^{\mathrm{s}}$ & $0,006000^{\mathrm{s}}$ & 0,131000 \\
\hline 2. & $\begin{array}{l}\text { Contribution of } \\
\text { Government } \\
\text { Consumption }\left(\mathrm{X}_{2}\right)\end{array}$ & 0,371000 & $2,702000^{\mathrm{s}}$ & $0,015000^{\mathrm{s}}$ & 0,137000 \\
\hline 3. & $\begin{array}{l}\text { Contribution of } \\
\text { investment }\left(\mathrm{X}_{3}\right)\end{array}$ & 0,257000 & $2,467000^{\mathrm{s}}$ & $0,025000^{\mathrm{s}}$ & 0,104000 \\
\hline 4. & $\begin{array}{l}\text { Contribution of net } \\
\text { export }\left(\mathrm{X}_{4}\right)\end{array}$ & 0,358000 & $3,429000^{\mathrm{s}}$ & $0,003000^{\mathrm{s}}$ & 0,104000 \\
\hline
\end{tabular}


Information :

$\mathrm{t}_{\text {table }}=\mathrm{t}_{0,05(20)}(\mathrm{t}$ table at $\alpha=5 \%$ of 1 -sided test type and $\mathrm{db}=\mathrm{n}-\mathrm{k}=21) \mathrm{b}_{\mathrm{i}}=$ regression coefficient, $\mathrm{r}_{\mathrm{YXiXk}}=$ partial correlation coefficient, $\mathrm{ns}=$ non-significant, $\mathrm{s}=$ significant

Based on the series of hypothesis testing above, which examines the effect of independent variables (household consumption, government consumption, investment and net export) on dependent variable (Gross Regional Domestic Product / GRDP), the equation obtained from the regression analysis are as follow:

$Y=0,206000+0,407000 X_{1}+0,371000 X_{2}+0,257000 X_{3}+0,358000 X_{4}$

The multiple regression equation can be interpreted as follows:

a. If there is no household consumption $\left(\mathrm{X}_{1}\right)$ and government consumption $\left(\mathrm{X}_{2}\right)$, investments $\left(\mathrm{X}_{3}\right)$ and net exports $\left(\mathrm{X}_{4}\right)$, the Gross Regional Domestic Product $(\mathrm{Y})$ only reached 0,206000.

b. If only the element of household consumption $\left(\mathrm{X}_{1}\right)$ is carried out in the absence of government consumption, investment and net export $\left(\mathrm{X}_{2}, \mathrm{X}_{3}\right.$ and $\mathrm{X}_{4}$ constant), then every increase in household consumption $\left(\mathrm{X}_{1}\right)$ of Rp 1,- will increase the Gross Regional Domestic Product (Y) amounted to 0,407000.

c. If only the element of government consumption $\left(\mathrm{X}_{2}\right)$ is carried out in the absence of household consumption, investment and net export $\left(\mathrm{X}_{1}, \mathrm{X}_{3}\right.$ and $\mathrm{X}_{4}$ constant), then every increase in government consumption $\left(\mathrm{X}_{2}\right)$ of $\mathrm{Rp} 1$,- will increase the Gross Regional Domestic Product ( $\mathrm{Y}$ ) amounted to 0,371000.

d. If only the investment element $\left(\mathrm{X}_{3}\right)$ are carried out in the absence of household consumption, government consumption and net exports $\left(\mathrm{X}_{1}, \mathrm{X}_{2}\right.$ and $\mathrm{X}_{4}$ constant), then any increase in investment $\left(\mathrm{X}_{3}\right)$ of $\mathrm{Rp} 1$,- will increase the Gross Regional Domestic Product (Y ) amounted to 0,257000.

e. If only the element of net export $\left(\mathrm{X}_{4}\right)$ is carried out in the absence of household consumption, government consumption and investment $\left(\mathrm{X}_{1}, \mathrm{X}_{2}\right.$ and $\mathrm{X}_{3}$ constant), then any increase in net exports $\left(\mathrm{X}_{4}\right)$ of $\mathrm{Rp} 1$,- will increase the Gross Regional Domestic Product ( Y) amounted to 0,358000.

\section{Testing of Model 2}

The effect of Gross Regional Domestic Product (GRDP) on the Human Development Index (HDI), it can be seen in the table below.

Table 4.3. Testing of the Effect of Gross Regional Domestic Product (GRDP) on Human Development Index (HDI)

Dependent Variable: Z1

Method: Least Squares

Date: $12 / 17 / 13$ Time: $11: 30$

Sample: 19912012

Included observations: 23

\begin{tabular}{crcrc}
\hline \hline Variable & Coefficient & Std. Error & t-Statistic & Prob. \\
\hline \hline $\mathrm{C}$ & 0.004000 & 0.125000 & 0.031000 & 0.957000 \\
$\mathrm{Y}$ & 0.019000 & 0.004000 & 4.507000 & 0.000000 \\
\hline \hline R-squared & 0.504000 & Mean dependent var & & 0.535500 \\
Adjusted R-squared & 0.47900 & S.D. dependent var & & 0.274080 \\
\hline \hline
\end{tabular}

Source : Data Processing of Eviews 7.0 (2013)

Based on the output result in the table above shows that the contribution of the effect of Gross Regional Domestic Product (GRDP) on Human Development Index (HDI) in Tangerang Regency is 50,4\% (R Square = 0,504000 ), while the remaining $49,6 \%$ is influenced other factors that are not examined as public income, social welfare etc. The value of adjusted $\mathrm{R}^{2}$ (Adjusted $\mathrm{R}$-squared) is obtained by 0,479000 .

The results of $t$ test can be explained as follows:

a. Result of t table with degrees of freedom $n-k=23-2=21$ is obtained t Table on the degree of confidence of $95 \%$ amounting to 2,086 .

b. Result of t count to the regression coefficient of Gross Regional Domestic Product variable is 4,507000 (Sig. $=0,000000)$.

c. $t_{\text {count }}$ is greater than $t_{\text {table }}(4,507000>2,086)$, the Gross Regional Domestic Product (GRDP) significantly affects Human Development Index (HDI) in Tangerang regency. 
Based on the above hypothesis testing series, which examines the effect of independent variables (Gross Regional Domestic Product/GRDP) on dependent variable (Human Development Index/HDI), the equation obtained from regression analysis as follows:

\section{$\mathrm{Z}_{1}=0,004000+0,019000 \mathrm{Y}$}

The simple regression equation can be interpreted as follows:

a. If there is no Gross Regional Domestic Product/GRDP (Y), the Human Development Index/ HDI (Z1) is only 0,004000 .

b. If there is Gross Regional Domestic Product/GRDP (Y), then every increase in Gross Regional Domestic Product/GRDP (Y) of Rp 1,- will increase Human Development Index/HDI $\left(\mathrm{Z}_{1}\right)$ of 0,019000.

\section{Testing of Model 3}

The effect of Human Development Index (HDI) on the labor absorption, it can be seen in the table below

Table 4.4. Testing of the Effect of Human Development Index (HDI) on Labor Absorption

Dependent Variable: Z2

Method: Least Squares

Date: $12 / 17 / 13$ Time: $12: 00$

Sample: 19902012

Included observations: 23

\begin{tabular}{ccccc}
\hline \hline Variable & Coefficient & Std. Error & t-Statistic & Prob. \\
\hline \hline $\mathrm{C} 1$ & 0.006000 & 0.090000 & 0.069000 & 0.946000 \\
\multicolumn{1}{c}{} & 0.703000 & 0.150000 & 4.677000 & 0.000000 \\
\hline \hline R-squared & 0.522000 & Mean dependent var & & 0.382700 \\
Adjusted R-squared & 0.499000 & S.D. dependent var & & 0.266640 \\
\hline
\end{tabular}

Source : Data Processing of Eviews 7.0 (2013)

Based on the output result in table above shows that the contribution of the effect of Human Development Index (HDI) in labor absorption in Tangerang Regency is 52,2\% (R Square $=0,522000$ ), while the remaining $47.8 \%$ is influenced by other factors that are not examined such as labor force, employment opportunity and so forth. The value of adjusted $\mathrm{R}^{2}$ (Adjusted R-squared) obtained by 0,499000 .

The results of $\mathrm{t}$ test can be explained as follows:

a. Result of $\mathrm{t}$ table with degrees of freedom $\mathrm{n}-\mathrm{k}=23-2=21$ is obtained t Table on the degree of confidence of $95 \%$ amounting to 2,086 .

b. Result of t count for regression coefficient variable of Human Development Index (HDI) is 4,677000 (Sig. $=0,000000$ ).

c. $\quad \mathrm{t}$ hitung lebih besar dari $\mathrm{t}$ tabel $(4,677000>2,086)$, maka Indeks Pembangunan Manusia (IPM) berpengaruh signifikan terhadap penyerapan tenaga kerja di Kabupaten Tangerang.

d. $\quad T_{\text {count }}$ is greater than $t_{\text {table }}(4,677000>2,086)$, Human Development Index (HDI) has a significant effect on employment in Tangerang regency.

Based on the hypothesis testing series above, which examines the effect of independent variables (Human Development Index) on dependent variable (labor absorption), the equation obtained from the regression analysis is as follows:

$\mathrm{Z}_{2}=0,006000+0,703000 \mathrm{Z}_{1}$

The simple regression equation can be interpreted as follows:

a. If there is no Human Development Index/HDI $\left(Z_{1}\right)$, the labor absorption $\left(Z_{2}\right)$ is only 0,006000 .

b. If there is a Human Development Index/HDI $\left(Z_{1}\right)$, then any increase of 1 score in Human Development Index $\left(Z_{1}\right)$ will increase labor absorption $\left(Z_{2}\right)$ of 0,703000 .

\section{Testing of Model 4.}

The effect of Human Development Index (HDI) and labor absorption simultaneously on poverty, it can be seen in the table below: 
The Effect Of Aggregate Expenditure On Gross Regional...

Table 4.5. Testing of the Effect of Human Development Index (HDI) and Labor Absorption on Poverty

Dependent Variable: Z3

Method: Least Squares

Date: $12 / 17 / 13$ Time: $12: 30$

Sample: 19902012

Included observations: 23

\begin{tabular}{lrrrr}
\hline \hline \multicolumn{1}{c}{ Variable } & Coefficient & Std. Error & t-Statistic & Prob. \\
\hline \hline C & 2.446000 & 0.433000 & 5.642000 & 0.000000 \\
Z1 & -2.639000 & 1.048000 & -2.519000 & 0.021000 \\
\multicolumn{1}{c}{-2.401000} & 1.077000 & -2.230000 & 0.038000 \\
\hline \hline R-squared & 0.682000 & Mean dependent var & & 0.113600 \\
Adjusted R-squared & 0.648000 & S.D. dependent var & & 1.533090 \\
S.E. of regression & 33.649000 & & \\
Sum squared resid & 15.709000 & & \\
F-statistic & 20.349000 & & & \\
Prob(F-statistic) & 0.000000 & & & \\
\hline \hline
\end{tabular}

Based on the output results in the table above shows that the contribution of the effect of Human Development Index (HDI) and labor absorption together on poverty in Tangerang district is 68,2\% (R Square = Source : Data Processing of Eviews $7.0 \begin{aligned} & \text { by other factors that are not examined as public income } \\ & \text { ared) obtained by } 0,648000 \text {. }\end{aligned}$ The results of Hypothesis test of $\mathrm{F}$ can be explained as follows:

a. Results of $\mathrm{F}$ table with denominator degree $=\mathrm{n}-\mathrm{k}-1=23-2-1=20$ and numerator degree $=\mathrm{k}-1=3-$ $1=2$ is obtained $\mathrm{F}$ table at the confidence degree of $95 \%$ amounting to 3,52 .

b. Results of F count obtained F count is 20,349000.

c. $F_{\text {count }}$ larger than $F_{\text {table }}(20,349000>3,52)$, the effect of Human Development Index (HDI) and labor absorption simultaneously on poverty in Tangerang Regency is significant.

The contribution effect of Human Development Index (HDI) and labor absorption partially on poverty can be shown in the table below.

Table 4.23. : The Results of Partial Effect Test of Human Development Index and Labor Absorption on Poverty

\begin{tabular}{|c|l|c|c|c|c|}
\hline No. & \multicolumn{1}{|c|}{ Partial Effect } & $\mathbf{b}_{\mathbf{i}}$ & $\mathbf{T}_{\text {count }}$ & P-Value & $\begin{array}{c}\text { Standar } \\
\text { Error }\end{array}$ \\
\hline 1. & $\begin{array}{l}\text { Contribution of } \\
\text { Human Development } \\
\text { Index/HDI (Z) }\end{array}$ & $-2,639000$ & $-2,519000$ & $0,021000^{\mathrm{s}}$ & 1,048000 \\
\hline 2. & $\begin{array}{l}\text { Contribution of } \\
\text { Labor Absorption } \\
\left(\mathrm{X}_{2}\right)\end{array}$ & $-2,401000$ & $-2,230000$ & $0,038000^{\mathrm{s}}$ & 1,077000 \\
\hline
\end{tabular}

Inforamtion :

$\mathrm{t}_{\text {table }}=\mathrm{t}_{0,05(20)}$ (value of $\mathrm{t}$ table at $\alpha=5 \%$ of 1-side test type and $\left.\mathrm{db}=\mathrm{n}-\mathrm{k}=21\right) \mathrm{b}_{\mathrm{i}}=$ regression coefficient, $\mathrm{r}_{\mathrm{YXiXk}}=$ partial correlation coefficient, $\mathrm{ns}=$ non-significant, $\mathrm{s}=$ significant.

Based on the hypothesis testing series above, which examines the effect of independent variables (Human Development Index/HDI and labor absorption) on dependent variable (poverty), then the equation obtained from the regression analysis is as follows:

\section{$\mathrm{Z}_{3}=\mathbf{2 , 4 4 6 0 0 0}-\mathbf{2 , 6 3 9 0 0 0} \mathrm{Z}_{1}-\mathbf{2 , 4 0 1 0 0 0} \mathrm{Z}_{2}$}

The multiple regression equation can be interpreted as follows:

a. If there is no Human Development Index/HDI $\left(\mathrm{Z}_{1}\right)$ and labor absorption $\left(\mathrm{Z}_{2}\right)$, the poverty is only reached 2,446000 . 
b. If only the element of Human Development Index/HDI $\left(Z_{1}\right)$ is carried out in the absence of labor absorption $\left(Z_{2}\right.$ constant), then every increase of 1 score in Human Development Index/HDI $\left(Z_{1}\right)$ will decrease poverty $\left(\mathrm{Z}_{3}\right)$ of 2,639000 .

c. If only the element of labor absorption $\left(\mathrm{Z}_{2}\right)$ is carried out in the absence of Human Development Index/HDI ( $Z_{1}$ constant), then every increase of 1 score in labor absorption $\left(Z_{2}\right)$ will decrease poverty $\left(Z_{3}\right)$ of 2,401000.

\section{B. Discussion}

Based on the result of data processing mentioned above, the interpretation of data can be expressed as follows:

1. Testing Result of Model 1

The effect of household consumption, government consumption, investment and net export simultaneously on Gross Regional Domestic Product (GRDP).

The regression results of the effect of household consumption, government consumption, investment and net export simultaneously on Gross Regional Domestic Product (GRDP) shows the results of $R=0,919$ and $\mathrm{R}^{2}$ of 0,845 . It means that statistically the variable effect of household consumption, government consumption, investment and net export simultaneously on Gross Regional Domestic Product (GRDP) amounted to $84,5 \%$ while the remaining $15.5 \%$ is influenced by other factors that are not considered (examined ) in this model such as interest rates, foreign currency exchange rates, security and others.

The coefficient of household consumption $\left(\mathrm{X}_{1}\right)$ in Tangerang regency $=0,407$ units. Household consumption is highly dependent on the amount of income $\mathrm{C}=\mathrm{f}(\mathrm{Y})$, meaning that the higher the income, the higher the household consumption. The results of the regression coefficient is consistent with the results of $\mathrm{t}$ test (partial test) obtained $\mathrm{t}_{\text {count }}=3,111000>\mathrm{t}_{\text {tabel }} 20,86$.

Based on the results of data processing with regression coefficient of the effect of the aggregate expenditure is in line with the Keynes' opinion quoted Case and Fair (2004, p. 272) states that consumption is a function of income, then consumption will be able to increase income. In the theory of national income, the increase in national income will improve the welfare of community and household consumption will increase. The increase in household consumption will increase national income.

Furthermore Sadono Sukirno (2010, p 38) also states that income received by households is used to buy food, clothing, finance transport services, paying children's education, paying rent and buying vehicles, goods are purchased household to meet their needs. The increase of household demand to meet their needs and will increase the price and national output. Household consumption is used to consume goods and services and partly to save. Household consumption is the most dominant factor that affects the Gross Regional Domestic Product (GRDP). This reflects consumtive behavior of society in Tangerang regency is high.

The coefficient of government consumption $\left(\mathrm{X}_{2}\right)=0,371$ increases by 1 unit (household consumption, investment and net export are assumed to be constant) it will increase the GRDP (Yd) amounted to 0,371 units.

Based on the calculation coefficient above, it means that government consumption contributes to GRDP. This is consistent with the opinion of Rahman Mulyawan (2002, p 4:18) which states that the increase of consumption of local government for development is more aimed at improving infrastructure, such as the building of roads, ports, bridges, irrigation, electricity and others, thus government consumption which indirectly can increase the production of various sectors of economy.

Investment coefficient $\left(X_{3}\right)$ at $=0,257$, this means that if investment increases by one unit, while household consumption, government consumption and net exports are assumed to be constant, it will increase GRDP (Yd) 0,257 units. The increase of investment will increase aggregate spending in the economy and is used by company for purchase of capital goods and services in order to increase the ability to produce goods and services then it will increase the national income. Furthermore, additional investment will be an additional boost larger on national income, it is called to as the multiplier effect of investment or Multiplier Effect (Yuyun Wirasasmita, 2010).

From the four variables of aggregate expenditure, investment has the lowest impact on Gross Regional Domestic Product (GRDP) in Tangerang regency. This is because there are still many barriers to investment in Tangerang regency. The length of permitting process, the lack of infrastructure, frequent labor demonstration, damage of roads and bridges are factors that hinder investment.

Coefficient value of net export amounts to 0,358 increasing by 1 unit, while household consumption, government consumption and investment are considered constant, it will increase the GRDP (Yd) of 0,358 units.

The increase in total export minus total import will provide a positive contribution to Gross Regional Domestic Product (GRDP). This is in line with the opinion of Sadono Sukirno (2006, p. 125), which states that net export (X-M) is the most important factor in increasing the income for the country. 
2. Testing Results of Model 2.

The Effect of Gross Regional Domestic Product (GRDP) on Human Development Index (HDI).

Regression Results of the effect of Gross Regional Domestic Product on Human Development Index (Z1) shows $\mathrm{R}=0,543$ and $\mathrm{R}^{2}$ 0,504. This means that statistically the variable effect of Gross Regional Domestic Product (GRDP) on Human Development Index (HDI) is 50,4\% while the remaining 49,6,5\% is influenced by the other factors that are not considered (examined) in this study, such as: the level of income, community welfare, school-age population, Ratio of Student and Teacher, ratio of Total Medical, the number of health facilities and infrastructure and others.

Based on the regression results above, Gross Regional Domestic Product (GRDP) will increase Human Development Index (HDI). This is in line with what was once stated by Khodabakhshi (2011, p. 23) that Gross Domestic Product in India which is good has an impact on Human Development Index (HDI), although its effect is low.

3. Testing Results of Model 3.

The Effect of Human Development Index (HDI) on labor absorption.

The effect of Human Development Index (HDI) in the labor absorption indicate that the contribution effect of Human Development Index in the labor absorption in Tangerang regency shows R of 0,787 and $\mathrm{R}^{2}$ of $52,2 \%$ (R Square $=0,522000$ ). Statistically variables effect of Human Development Index (HDI) in labor absorption is $52,2 \%$ while the remaining $47,8 \%$ is influenced by other factors that are not considered (examined) in this study, such as: investment, industrial quantities available, vocation and skills (ability) of labor.

Based on the regression results above, Human Development Index (HDI) will increase labor absorption in Tangerang regency. This is because one of the elements in Human Development Index (HDI): education (the number of mean years of schooling and literacy rate) which is high will be able to improve skills and abilities of community so that they will be more easily absorbed in the world of work.

4. Testing Results of Model 4.

The effect of Human Development Index (HDI) and labor absorption on poverty.

The effect of Human Development Index (HDI) and labor absorption on poverty shows that the contribution of the effect of Human Development Index and labor absorption together on poverty in Tangerang regency shows $R$ of 0,825 and $R^{2}$ of $68,2 \%$ ( $R$ Square $=0,682000$ ), which means that the effect of HDI and labor absorption by $68 \%$ on poverty, while the remaining of $31,8 \%$ is influenced by other factors which are not considered in this model, such as investment, infrastructure, agricultural land, the number of jobs and etc.

Contribution of HDI on poverty by: $-2,639$, meaning if HDI increased by one unit, while labor absorption is considered constant, it will reduce poverty (Z3) 0,257 units.

The contribution of labor absorption to poverty by: $-2,410$, meaning if the labor absorption increased by one unit, while IPM is assumed to be constant, it will reduce poverty (Z3) of 0,257 units. This is in line with the study results of Muhammad S.W. Suliswanto (2010, p. 18) states that Human Development Index and Labor Absorption have a dominant effect on the magnitude of poverty in Indonesia. Human Development Index (HDI) and labor absorption have a negative effect on poverty it means that with increasing Human Development Index and employment will reduce poverty.

\section{Conclusion}

By considering the result of research data collection, data processing and interpretation of research data then some of conclusions in this study as follows:

1) There is a significant effect of household consumption, government consumption, investment and net export, either simultaneously or partially on Gross Domestic Regional Product in Tangerang Regency.

2) There is a positive and significant effect of Gross Regional Domestic Product on Human Development Index/HDI in Tangerang Regency. Gross Regional Domestic Product as an indicator of increased economic growth directly related to Human Development Index.

3) There is a positive and significant effect of Human Development Index/HDI variable increases on labor absorption in Tangerang regency. Human development index which is high in Tengerang regency facilitates graduates of secondary and higher education to be easily absorbed in industrial sector.

4) There is a negative and significant effect of variables of Human Development Index (HDI) and Labor Absorption, either simultaneously or partially on poverty Tangerang regency. Human Development Index and labor absorption directly can reduce the poverty. 


\section{REFFERENCES}

[1]. Abbas, Q., et. al., 2011. Impact of Foreign Direct Investment on Gross Domestic Product. Global Journal of Management and Business Research. Vol. 11, Issue 8 Version 1.0.

[2]. Abdul Hakim., 2002. Ekonomi Pembangunan. Yogyakarta : Penerbit Ekonisia.

[3]. Ahmad, H., et. al., 2012. Impact of Foreign Direct Investment on Gross Domestic Product. International Journal of Business and Management Tomorrow. Vol. 2, No. 3.

[4]. Al Khatib, H.B.,2011. Altaleb, G.S. and Alokor, S.M. Economical Determinants of Domestic Investment. European Scientific Journal. Vol. 8, No. 7..

[5]. $\quad$ Amir, M.S., 2004. Strategi Memasuki Pasar Ekspor. Jakarta : PPM.

[6]. Arsyad, Lincolin. 2010. Pengantar Perencanaan dan Pembangunan Ekonomi Daerah. Yogyakarta : BPFE.

[7]. $\quad$ Badan Pusat Statistik., 2009. Produk Domestik Regional Bruto Provinsi-Provinsi di Indonesia Menurut Lapangan Usaha 2004 2008. Jakarta : BPS

[8]. ., 2010. Statistik Indonesia. Jakarta : BPS

[9]. Badan Pusat Statistik Provinsi Banten., 2011. Analisis Pengaruh Kontribusi Pengeluaran Pemerintah Daerah terhadap Pertumbuhan Ekonomi dan Pembangunan Manusia di Provinsi Banten 2002 - 2010. Banten : Pemerintah Daerah Provinsi Banten dan BPS Provinsi Banten, 2011.

[10]. BPS Kabupaten Tangerang. Kabupaten Tangerang Dalam Angka. Tangerang : BPS Kabupaten Tangerang, 2013.

[11]. . 2013.Kabupaten Tangerang Dalam Angka. Tangerang : BPS Kabupaten Tangerang.

[12]. Bank Dunia., 2002. Dimensi Kemiskinan. Jakarta.

[13]. Becker, G. and Posner R., 2007. The UN's Human Development Index : A Critique - Posner.

[14]. Boediono., 2005. Ekonomi Makro. Cetakan Kedupuluh Satu. Yogyakarta : BPFE.

[15]. Borensztein, E., Gregorio, J.D., and Lee., 1998. How Does Foreign Direct Investment Affect Economic Growth ?. Journal of International Economics 45. Elsevier Science B.V.

[16]. Case and Fair., 2004. Prinsip-Prinsip Ekonomi Makro (Judul asli : Principles of Economics). Alih Bahasa : Benyamin Molan. Jakarta : PT. Indeks.

[17]. Chen, Martin P., 2002. Refleksi dari Praksis Kaum Miskin. Yogyakarta : Penerbit Kanisius.

[18]. Chen, Q. and Yang, C., 2011. The Impact of Expanding Household Consumption on the GDP of China. Journal of System Science and Mathematical Sciences.

[19]. Denni Sulistio Mirza., 2012. Pengaruh Kemiskinan, Pertumbuhan Ekonomi, dan Belanja Modal terhadap Indeks Pembangunan Manusia di Jawa Tengah Tahun 2006 - 2009. Economics Development Analysis Journal. Universitas Negeri Semarang.

[20]. Dumairy., 2004. Perekonomian Indonesia. Editor : Yati Sumiharti. Jakarta : Penerbit Erlangga.

[21]. Ghali, K.H., 1997. Government Spending and Economic Growth in Saudi Arabia. Journal of Economic Development. Vol. 22, No. 2, December.

[22]. Gujarati, Domodar., 2003. Dasar-dasar Ekonometrika (Basic Econometrics). Penerjemah : Raden Carlos Mangunsong. Buku 1 dan 2. Jakarta : Penerbit Erlangga.

[23]. Guritno Mangkoesoebroto., 2008. Ekonomi Publik. Yogyakarta : BPFE.

[24]. Hendra Halwani., 2005. Ekonomi Internasional \& Globalisasi Ekonomi. Edisi Kedua. Bogor : Ghalia Indonesia.

[25]. Hseis, E. and Lai, K.S., 1994. Government Spending and Economic Growth : the G-7 Experience. Applied Economics, California : California State University.

[26]. Islam, Rizwanul., 2004. The Nexus of Economic Growth, Employment and Poverty Reduction : an Empirical Analysis. Issue in Employment and Poverty Discussion Paper. Recovery and Reconstruction Department International Labour Office, Geneva.

[27]. Jhingan, M.L., 2000. Ekonomi Pembangunan dan Perencanaan (Judul asli : The Economics Of Development And Planning). Alih Bahasa D. Guritno, Jakarta : PT Raja Grafindo.

[28]. Khodabakhshi, A., 2011. Relationship between GDP and Human Development Indices in India. International Journal of Trade, Economics and Finance, Vol. 2. No. 3, June.

[29]. Koutsoyiannis., 1975. Modern Microeconometrics: The Macmillan Press Ltd., United Kingdom.

[30]. Lynn, Stuart R., 2003. Economic Development : Theory and Practice for Divided World. New Jersey : Prentice Hall.

[31]. Masri Singarimbun dan Sofyan Effendi., 2008. (Editor). Metode Penelitian Survai. Jakarta : LP3ES.

[32]. Mudrajad Kuncoro., 2000. Ekonomi Pembangunan. Teori, Masalah dan Kebijakan. Cetakan Kedua. Yogyakarta : UPP AMP YKPN.

., 2013. Mudah Memahami dan Menganalisis Indikator Ekonomi. Cetakan Pertama. Yogayakarta : UPP STIM YKPN.

[34]. Mulyadi S., 2008. Ekonomi Sumber Daya Manusia. Dalam Perspektif Pembangunan. Jakarta : Rajawali Pres.

[35]. Patriotika, Mashita Prima., 2013. Faktor-faktor yang Mempengaruhi Indeks Pembangunan Manusia di Jawa Barat, 2011. http://repository.ipb.ac.id/handle/123456789/53115. Download Tanggal 17 April.

[36]. Pradhan, N.C., 2010. Exports and Economic Growth : An Examination of ELG Hypothesis for India. Reserve Bank of India Occasional Papers. Vol. 31, No. 3, Winter.

Pratama Rahardja dan Manurung, Mandala., 2008. Pengantar Ilmu Ekonomi (Mikroekonomi dan Makroekonomi). Jakarta : Lembaga Penerbit Fakultas Ekonomi Universitas Indonesia, 2008.

[38]. Sachs, Jeffrey., 2005. The End of Poverty : How We Can Make it Happen in Our Lifetime. London : England, Penguin Bools.

[39]. Sadono Sukirno., 2006. Ekonomi Pembangunan : Proses, Masalah dan Dasar Kebijakan. Edisi Kedua. Cetakan Ke-1. Jakarta : Kencana Prenada Media Group.

[40].
[41]. 2010. Makroekonomi. Teori Pengantar. Edisi Ketiga. Jakarta : PT. RajaGrafindo Persada.

[41]. Sekaran, Uma., 2006. Research Methods for Business. Metodologi Penelitian untuk Bisnis. Penerjemah : Kwan Men Yon. Jakarta : Salemba Empat.

[42]. Sitiarava Rizema Putra., 2011. Cara Mudah Tembus Pasar Ekspor. Yogyakarta : Flashbooks.

[43]. Smith, Stephen C., 2005. Endind Global Poverty: A Guide to What Work. New York : Palgrave Macmillan.

[44]. Sony Sumarsono., 2003. Ekonomi Manajemen Sumber Daya Manusia dan Ketenagakerjaan. Yogyakarta : Penerbit Graha Ilmu.

[45]. Sugiyono., 2005. Metode Penelitian Bisnis. Cetakan Kedelapan. Bandung : Alfabeta.

[46]. Suliswanto, Muhammad S.W., 2010. Pengaruh Produk Domestik Bruto (PDB) dan Indeks Pembangunan Manusia (IPM) terhadap Angka Kemiskinan di Indonesia. Jurnal Ekonomi Pembangunan, Vol 8 No. 2, Desember 2010. http://ejournal.umm.ac.id 
[47]. $\quad$ Sumitro Djojohadikusumo., 1991. Perkembangan Pemikiran: Dasar Teori Ekonomi Pertumbuhan dan Pemerataan. Buku II. Jakarta : Penerbit PT. Pustaka LP3ES.

[48]. Suradi., 2007. Pembangunan Manusia, Kemiskinan dan Kesejahteraan Sosial. Jurnal Penelitian dan Pengembangan Kesejahteraan Sosial, Vol 12, No 03.

[49]. Suryadi., 2012. Statistika Ekonomi \& Sosial. Jakarta : Program Pascasarjana Universitas Negeri Jakarta.

[50]. Suryana., 2000. Ekonomi Pembangunan : Problematika dan Pendekatan. Jakarta : Salemba Empat.

[51]. Todaro, M., 2000. Pembangunan Ekonomi Dunia Ketiga. Terjemahan : Haris Munandar. Jilid 1. Edisi ke-6. Jakarta : Erlangga.

[52]. Triyanto Widodo Suseno., 1991. Indikator Ekonomi : Dasar Perhitungan Perekonomian Indonesia. Yogyakarta.

[53]. Tulus T. H. Tambunan., 2009. Perekonomian Indonesia. Jakarta : Penerbit Ghalia Indonesia.

[54]. Undang-Undang Republik Indonesia Nomor 13 Tahun 2003. Tentang Ketenagakerjaan.

a.

Whisnu Adi Saputra., 2013. Analisis Pengaruh Jumlah Penduduk,

PDRB, IPM, Pengangguran terhadap Tingkat Kemiskinan di Kabupaten/Kota Jawa Tengah. 2011. http://eprints.undip.ac.id. Downloaded at $18^{\text {th }}$ April.

[55]. Wing Wahyu Winarno., 2009. Analisis Ekonometrika dan Statistika dengan Eviews. Edisi Kedua. Yogyakarta : UPP STIM YKPN.

[56]. Yuyun Wirasasmita., 2006. Makro Ekonomi. Buku Ajar. Jakarta : Program Doktor Ilmu Ekonomi Universitas Borobudur.

[57]. _. 2008. Uji Kelayakan Model. Bandung : Fakultas Ekonomi Universitas Pajajaran, 2008.

[58]. 2008. Ekonomi Pembangunan. Buku Ajar. Jakarta : Program Doktor Ilmu Ekonomi Universitas Borobudur, 2008.

[59].

2010. Ekonomi Publik. Buku Ajar. Jakarta : Program Doktor Ilmu Ekonomi Universitas Borobudur. 